\title{
SOSIALISAS DAN PENYULUHAN TENTANG PENTINGNYA MEMILIH SEKOLAH DAN JURUSAN YANG TEPAT DI SEKOLAH MENENGAH ATAS BAGI GENERASI MUDA
}

\author{
Nahoras Bona Simarmata, Yenny Merinatul Hasanah, Ade Rachmawan, \\ Indri Indirasari, Laila Irawati \\ Universitas Pamulang \\ Email: dosen01002@unpam.ac.id
}

\begin{abstract}
Puri Serpong 1 is a residential area located in South Tangerang, precisely on Jl. Puspitek Raya, Setu District, South Tangerang. Located in an area that is rapidly growing, making residential areas in this area has a promising investment value. This encourages the government and society to take precautionary movements and actions to choose the right schools for children. Some of the efforts that have been made are providing socialization on the importance of choosing the right department and school for children to maximize the existing abilities of the child. There are still people who think that the right department or school is not important for their children. This makes many children or parents confused after the child leaves school where to go to work or continue studying. This PKM activity aims to provide socialization to people who still do not understand about choosing the right majors and schools for children according to children's interests and talents. The focus of PKM activities is the community around the Puri Serpong 1 area, which is a residential area located in South Tangerang, precisely on Jl. Puspitek Raya, Setu District, South Tangerang. This PKM has succeeded in providing more understanding to the community about the benefits of choosing the right department and school for children.
\end{abstract}

Keywords: Socialization, outreach.

\begin{abstract}
Abstrak
Puri Serpong 1 merupakan perumahan yang berada di Tangerang Selatan tepatnya di Jl. Puspitek Raya Kecamatan Setu Tangerang Selatan. Berlokasi di kawasan yang sangat pesat pertumbuhannya, menjadikan hunian di kawasan ini memiliki nilai investasi yang menjanjikan. Hal ini mendorong pemerintah dan masyarakat melakukan pergerakan dan tindakan antisipasi untuk memilih sekolah yang tepat pada anak-anak. Beberapa upaya yang telah dilakukan adalah dengan memberikan sosialisasi pentingnya memilih jurusan dan sekolah yang tepat bagi anak untuk memaksmalkan kemampuan yang ada pada anak. Masih ditemukannya masyarakat yang menganggap tidak pentingnya jurusan atau sekolah yang tepat bagi anaknya. Hal ini membuat banyaknya anak atau orang tua yang bingung setelah anak lulus sekolah mau kemana kerja atau lanjut kuliah. Kegiatan PKM ini bertujuan untuk memberikan sosialisasi kepada masyarakat yang masih belum paham tentang pemilihan jurusan da sekolah yang tepat bagi anak sesuai dengan
\end{abstract}


minat dan bakat anak. Fokus dari kegiatan PKM adalah masyarakat di sekitar wilayah Puri Serpong 1 merupakan perumahan yang berada di Tangerang Selatan tepatnya di Jl. Puspitek Raya Kecamatan Setu Tangerang Selatan. PKM ini telah berhasil memberikan pemahaman lebih kepada masyarakat tentang manfaat pemilihan jurusan dan sekolah yang tepat bagi anak-anak.

Kata Kunci: Sosialisasi, Penyuluhan.

\section{A. PENDAHULUAN}

Madrasah Tsanawiyah (MTs) Mathlaul Anwar Pamulang sebagai mitra pengabdian kepada masyarakat ini berlokasi di Jl. H. Rean No.111, RT.03/RW.01, Benda Baru, Kec. Pamulang, Kota Tangerang Selatan, Banten 15415. Lokasi mitra yang tidak terlalu jauh dari kampus pusat Universitas Pamulang dianggap cocok untuk dijadikan lokasi pengabdian kepada masyarakat. Sebagai target untuk penyampaian materi penyuluhan dan sosialisasi menabung ini adalah para siswa - siswi kelas IX yang mana mereka akan beranjak dewasa dan akan melanjutkan pendidikan mereka ke jenjang yang lebih tinggi yaitu SLTA. Mitra dalam PKM kali ini, yaitu para pelajar kelas IX Madrasah Tsanawiyah (MTs) Mathlaul Anwar Pamulang.

Pendidikan merupakan hal paling penting dan investasi masa depan bagi suatu negara. Pendidikan merupakan upaya sadar dan terencana dalam menyiapkan pembangunan masyarakat Indonesia untuk meningkatkan taraf hidup masyarakat untuk menjadi lebih baik. Supaya mampu mengenal, memahami, menghayati, dan mengamalkan amanat undangundang tentang pendidikan nasional salah satu program yang dapat menyiapkan ke arah perkembangan dan pembangunan masyarakat Indonesia masa depan yaitu dengan pendidikan. Oleh karena itu, melalui kegiatan bimbingan, pengajaran latihan, serta penggunaan pengalaman diharapkan terjadinya perubahan taraf kehidupan masyarakat Indonesia.

Pemerintah mengupayakan pembangunan manusia Indonesia melalui program pendidikan yang dapat memberikan akses dan pemerataan perolehan pendidikan bagi masyarakat Indonesia tanpa terkecuali. Langkah pemerintah Indonesia dalam menangani masalah pemerataan pendidikan melalui pencanangan program wajib belajar yaitu melalui Sekolah Dasar (SD) selama 6 tahun, kemudian wajib belajar 9 tahun melalui Sekolah Lanjutan Tingkat Pertama (SLTP) selama 3 tahun. Kebijakan ini disebut sebagai upaya menerapkan pendidikan minimal yang harus dimiliki oleh seluruh masyarakat Indonesia yang erat kaitannya dengan gerakan "melek" huruf dan masyarakat belajar. Oleh karena itu, pencanangan program wajib belajar di Indonesia erat kaitannya dengan pemberian layanan publik dalam bidang pendidikan yang dapat memberikan fasilitas pendidikan seluas-luasnya bagi seluruh masyarakat Indonesia dengan tujuan meratanya pendidikan di Indonesia serta dapat berpengaruh pada jumlah anak yang tidak sekolah atau putus sekolah supaya dapat belajar dengan baik.

Hasil yang diperoleh dalam proses belajar adalah adanya perubahan tingkah laku dan mendapatkan pengalaman-pengalaman baru pada individu masing-masing. Pemilihan jurusan yang tepat bagi siswa kelas 9 adalah hal yang sangat penting. Namun, kenyataannya banyak siswa kelas 9 yang masih bingung memilih jurusan apa yang cocok dengan mereka. Ini sangat disayangkan mengingat pemilihan jurusan yang cocok adalah hal yang utama saat melanjutkan ke tingkat pendidikan menengah. 
Harapan besar setelah penyuluhan dan sosialisai peserta didik Madrasah Tsanawiyah (MTs) Mathlaul Anwar Pamulang dapat pemahaman mengenai pentingnya ketepatan dalam mengambil jurusan untuk melanjutkan jejang pendidikan selanjutnya seuai dengan kemampuan dan bakat yang dimiliki supaya potensi yang ada dalam diri mampu dikemangkan secara maksimal sesuai dengan amat UU Sistem Pendidikan Nasional Republik Indonesia.

\section{B. METODE PELAKSANAAN KEGIATAN}

Lokasi penelitian bertempat di Puri Serpong I RT 06 RW 02 Kecamatan Setu Tangerang Selatan. PKM dilaksanakan selama tiga hari, yaitu 3-5 Juli 2020. Metode kegiatan pengabdian kepada masyarakat yang digunakan adalah memberikan penyuluhan dan mensosialisasikan tentang pentingnya menabung. Sehubungan masih dalam masa PSBB di wilayah Tangerang Selatan maka metode yang di gunakan dalam kegiatan Pengabdian Kepada Masyarakat ini adalah dengan Webinar menggunakan aplikasi Zoom Meeting.

\section{HASIL DAN PEMBAHASAN}

Kegiatan pengabdian kepada masyarakat dilakukan oleh tim dosen Universitas Pamulang dalam rangka memenuhi salah satu Tri Dharma perguruan tinggi. Ada beberapa metode yang digunakan dalam kegiatan pengabdian kepada masyarakat dengan tema memilih jurusan dan sekolah yang tepat pada anak-anak di lingkungan RT 06 RW 02 Komp. Puri Serpong I Setu Tangerang Selatan. Sebelum pelaksanaan kegiatan pengabdian kepada masyarakat, tim pengabdian mematangkan persiapan matang agar pelaksanaan PKM dapat berjalan lancar sesuai dengan skenario yang telah dibuat. Langkah pertama yang ditempuh adalah menyiapkan berbagai peralatan yang dibutuhkan seperti pemesanan masker pembuatan pamflet atau selebaran dan juga pembelian hand sanitizer.

Pada mulanya tim PKM berencana melakukan audiensi dan perizinan kepada pemerintahan kelurahan Komp. Puri Serpong I Setu Tangerang Selatan. Akan tetapi karena beberapa pertimbangan dan kendala dalam pelaksanaan kegiatan PKM yang sudah dijelaskan dalam bab sebelumnya maka tim penelitian kepada masyarakat mempersempit wilayah pelaksanaan kegiatan PKM dan melakukan perizinan hanya kepada pemerintah RT setempat.

Berdasarkan hasil survei dan observasi tim PKM pada awal pelaksanaannya, masih banyakya anak-anak dan orang tua bingung dalam menentukan juruan apa dan sekolah dimana. Apalagi dengan kondisi saat sekarang dimana masyarakat tidak bebas beraktivitas diluar rumah karena adanya pendemi virus covid-19 yang menambah kebingungan pada anak dan orang tua.

Kegiatan pengabdian kepada masyarakat yang dilakukan dosen Universitas Pamulang dilaksanakan walaupun kegiatan ini dilaksanakan melalui aplikasi ZOOM. Kegiatan yang dilakukan dalam pengabdian kepada masyarakat ini yaitu terus melakukan pendekatan kepada masyarakat dan anak-anak untuk memilih jurusan dan sekolah yang tepat. Selanjutnya tim PKM juga memberikan beberapa alat pelindung minimal yang harus digunakan masyarakat sebagai upaya pencegahan virus covid 19 .

Fokus sasaran kegiatan PKM adalah anak-anak dan oang tua. Ternyata masih ditemukan masyarakat khususnya para orang tua yang sibuk bekerja tidak memikirkan jurusan atau sekolah yang tepat pada anaknya melainkan yang penting anak tetap melanjutkan sekolah. Setelah mendapat pengertian dan pemahaman mereka pun sepakat dan 
mau serta berkeinginan untuk turut berpartisipasi dalam memilih jurusan dan sekolah yang tepat bagi anak sesuai dengan bakat dan minat anak supaya kemampuan yang dimiliki anak dapat berkembang secara maksimal.

\section{KESIMPULAN DAN SARAN}

\section{Kesimpulan}

Kegiatan Pengabdian Kepada Masyarakat dengan "Sosialisasi Dan Penyuluhan Tentang Pentingnya Memilih Sekolah Dan Jurusan Yang Tepat Di Sekolah Menengah Atas Bagi Generasi Muda" yang telah dilaksanakan oleh tim pengabdian kepada masyarakat program studi Manajemen terlaksana dengan baik walaupun terdapat perubahan rencana pelaksanaannya. Kegiatan berlangsung selama tiga hari. Acara ini terlaksana atas kerjasama dengan berbagai pihak seperti Yayasan Sasmita Jaya, para dosen Program Studi Manajemen dan dan masyarakat di wilayah lingkungan RT 06 RW 02 Komp. Puri Serpong I Setu Tangerang Selatan. Kegiatan PKM ini telah memberikan kontribusi nyata dalam upaya pencegahan putus sekolah atau salah masuk jurusan yang tidak sesuai dengan minat dan bakat anak melalui sosialisasi dan pemberian bantuan kepada masyarakat dalam bentuk pembagian pengetahuan tentang jurusan dan sekolah yang tepat.

\section{Saran}

Dari kegiatan pengabdian kepada masyarat ini kami menyarankan agar semua pihak turut serta dalam mendukung kemauan anak dalam memilih jurusan atau sekolah sesuai dengan bakat dan minat anak. Ini karena data menunjukkan bahwa anak yang tidak tepat dalam memutuskan jurusan dan sekolah yang dipilih terbilang masih banyak. Orang tua tidak boleh mengabaikan apa yang menjadi keinginan anak dan harus mengarahan anak dalam mengembangkan kemampuan anak secara maksimal.

\section{DAFTAR PUSTAKA}

Aidil Amin Effendy., et all. (2020). Implementasi Kewirausahaan dan Koperasi di Sekolah Pada SMK Mulia Buana, Parung Panjang - Kab. Bogor. DEDIKASI PKM. Vol. 1. No. 2.

Angga Juanda., et all. (2020). Menumbuhkan Rasa Gotong Royong Dan Interaksi Sosial Di Kelurahan Pondok Jaya Kota Tangerang Selatan. DEDIKASI PKM. Vol. 1. No. 2.

Arnaldi, M. (2011). Effectivity metode intervenesmeta kognisi for learning disability of children inindonesia. Procedia-Social and Behavioral Sciences. ICEEPSY, 29, 164-169.

Dumilah, R., Sunarto A., Ahyani., Solihin, D., dan Maulida H. (2020). Pelatihan Pemanfaatan Media Sosial Untuk Promosi Usaha Atau Bisnis Bagi Siswa. DEDIKASI PKM. Vol. 1. No. 1.

Finatariani, E., Setianingsih., Anisa., Zenabia, T., dan Abdurachman, T. A. (2020). Pengelolaan Keuangan Keluarga Dan Pengenalan Dasar-Dasar Investasi Menuju Keluarga Mandiri Bagi Ibu-Ibu Majelis Taklim Al Auladiyah, Tangerang Selatan. DEDIKASI PKM. Vol. 1. No. 2. 
Illeris, K. (2009). Contemporary theories of learning: Learning theorist in their own word. New York: Routledge

Ormrod, J.E. (2012). Human learning (6thed.). New York: Pearson Education, Inc.

Purwanti, Andhani D., Simangunsong. R.R., Nelsi, M., dan Yunanti, S. (2020). Membangun Mental Wirausaha Untuk Meningkatkan Taraf Hidup Masyarakat Rt 006 Rw 10 Kp Cimuncang Destasikmalaya Karangnunggal Kabupaten Propinsi Jawa Barat. DEDIKASI PKM. Vol. 1. No. 2. 